Gut., 1973, 14, 178-182

\title{
The effect of perfusion on the flora of the excluded colon
}

\author{
ANGELA VINCE, R. BOWN, F. O'GRADY, AND A. M. DAWSON \\ From the Department of Bacteriology, St Bartholomew's Hospital, London
}

SUMMARY The bacterial flora of excluded colonic segments of three patients has been examined in the normal resting state and following perfusion.

The flora of the excluded colon was substantial and qualitatively similar to that of faeces.

Perfusion for two hours at $10 \mathrm{ml}$ per minute usually reduced counts of organisms present in the issuing effluent by 1 to $1 \frac{1}{2} \operatorname{logs}$ in two patients, but rises in the counts of some organisms were recorded from the third patient. Prolonged rapid perfusion or the inclusion of antibiotics in the perfusing solution was necessary to obtain a substantial reduction in counts.

Rapid perfusion resulted in the appearance of organisms that had not been recovered during slower perfusions.

Cleansing of the colon by continuous transcolonic irrigation has been recommended as an effective therapeutic measure in the treatment of hepatic coma (Wolpert, Phillips, and Summerskill, 1970). Ammonia is incriminated in the pathogenesis of hepatic coma and the major site of ammonia production in man is the colon. Most of the ammonia is thought to be produced by bacteria, either from hydrolysis of urea or by deamination of proteins and protein derivatives.

Studies on colonic perfusates have demonstrated a reduction in ammonia content during perfusion (Castell and Moore, 1968; Wolpert et al, 1970) and this has been used as an index of cleansing. No attempt has been made to assess the effect of perfusion on the bacterial population. It has been suggested that recovery of urea perfused through the colon could be due to cleansing of the colon of its normal bacteria-rich contents (Lancet, 1971). However, while it is reasonable to assume that continual washing through of the colon would reduce its bacterial content to a minimum, there is no evidence that it does so.

The present study was initiated to examine the effect of perfusion on the bacterial population of excluded colonic segments as a part of our investigation of the handling of ammonia by this organ (Bown, Sladen, Clark, and Dawson, 1972). Besides determining the effect of routine steady-state perfusion over a two-hour period, more rigorous

Received for publication 20 December 1972. methods, aimed at obtaining a significant quantitative reduction in the flora, were adopted. These consisted of rapid perfusion at $50 \mathrm{ml}$ per minute for an hour, following immediately after a routine twohour perfusion, and the incorporation of neomycin and lincomycin into the solution used for perfusion.

\section{Materials and Methods}

\section{PATIENTS}

Three male patients were studied. They had undergone colonic exclusion for chronic hepatic encephalopathy between six months and three years previously.

NATURAL EFFLUENT AND FAECES

Specimens of natural colonic secretion were obtained from each patient, from two of whom faecal specimens were obtained on the same day.

\section{PERFUSION STUDIES}

Numerous specimens were obtained from the three patients during perfusion of the colonic segment with a phosphate-buffered, protein-free solution, the $\mathrm{pH}$ of which varied from 4.2 to 8.9 on different occasions (Bown, Sladen, Rousseau, Gibson, Clark, and Dawson).

Most perfusions were performed at $10 \mathrm{ml} / \mathrm{min}$ but two perfusions were performed at $50 \mathrm{ml} / \mathrm{min}$. Specimens collected were: (1) the first fluid to emerge from the distal stoma after perfusion had been instigated, and (2) fluid emerging after two hours of steady-state perfusion. They were delivered 
to the laboratory immediately and examined for their bacteriological content as described previously (Hamilton, Dyer, Dawson, O'Grady, Vince, Fenton, and Mollin, 1970; Zeegen, Drinkwater, Fenton, Vince, and Dawson, 1970).

\section{ANTIBIOTIC PERFUSIONS}

These contained $80 \mathrm{mg}$ neomycin and $20 \mathrm{mg}$ lincomycin per litre-an estimated 10 times the minimum inhibitory concentration of organisms to be eradicated. Organisms recovered during previous perfusions were shown to be fully sensitive to these agents using sensitivity discs. Organisms recovered during perfusion with the antibiotic-containing solution were tested against the perfusate and the issuing effluent, and against $1 / 10$ and $1 / 20$ dilutions of them by the whole plate technique.

\section{Results}

\section{NATURAL EFFLUENT}

The flora of natural effluent from the excluded colon of three patients is given in figure 1 . The faecal flora of two of the three patients is included for comparison. The flora of the excluded colon was substantial and qualitatively similar to that of faeces. Although comparison with the faecal flora was only made in two instances, it appeared that counts of aerobic organisms in the colonic effluent tended to be equal to, or higher than, those in faeces and that counts of anaerobic organisms in colonic effluent were usually equal to or less than those in faeces. Yeasts were isolated from the faeces but not from the colonic effluent in subject 2 . Conversely, three or four species of enterobacteria were recovered from the colonic effluent of both patients compared with only two from the faeces, although both specimens were obtained on the same day. Serotyping of the Esch. coli from two subjects indicated that the dominant Esch. coli was of the same type in the faeces and the colonic effluent.

\section{PERFUSION EFFLUENT}

Steady-state perfusion at $10 \mathrm{ml}$ per minute

The mean counts of the major groups of colonic organisms present in three subjects before and after two hours of perfusion at $10 \mathrm{ml}$ per min are given in the table. Twenty perfusions were performed. The effect of perfusion in subjects 1 and 2 was usually to reduce the counts of most organisms present by 1 to $1 \frac{1}{2}$ logs, although more dramatic falls did occur occasionally. However, in some instances counts of organisms were not decreased by perfusion, and small increases of up to $\frac{1}{2}$ a log were observed in the counts of three organisms, enterococci, lactobacilli, and bifidobacteria, on three separate occasions. The
SUBJECT

1

2

3

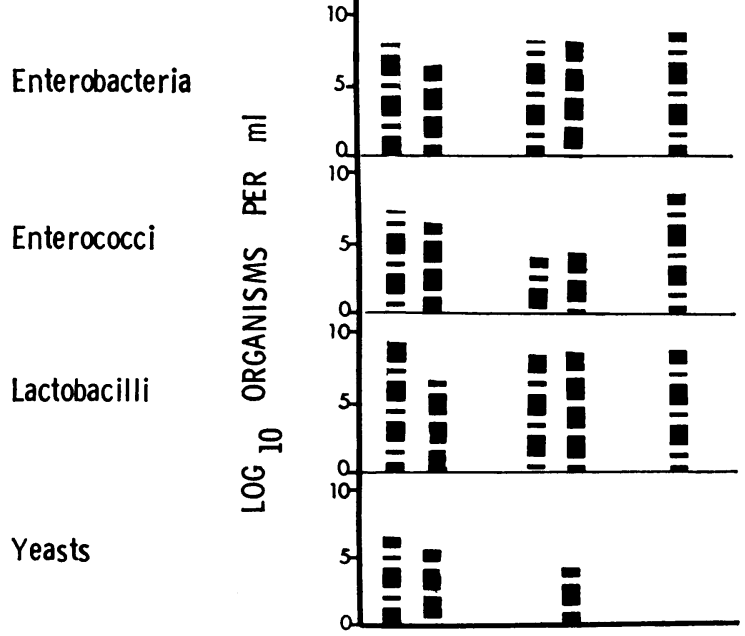

1

2

3

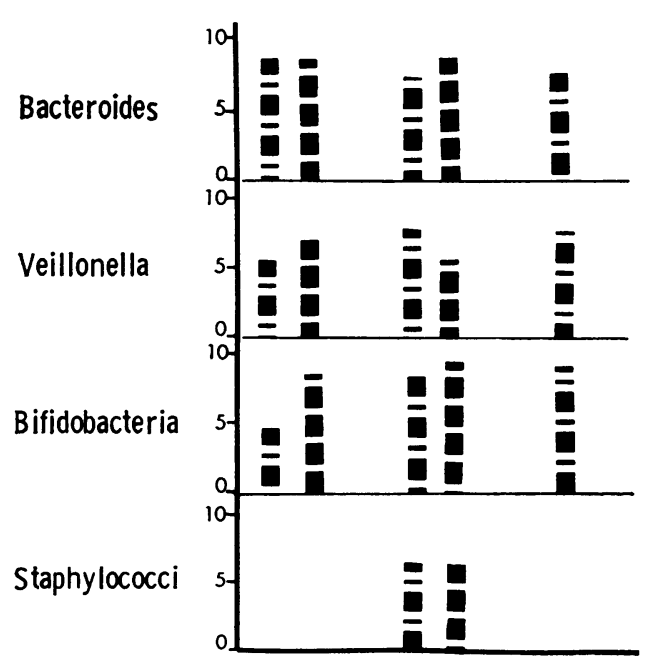

IDIE Natural effluent

100. Faeces

Fig. 1 The flora of natural effluent from the excluded colon of three patients compared with the faecal flora of two of them. 


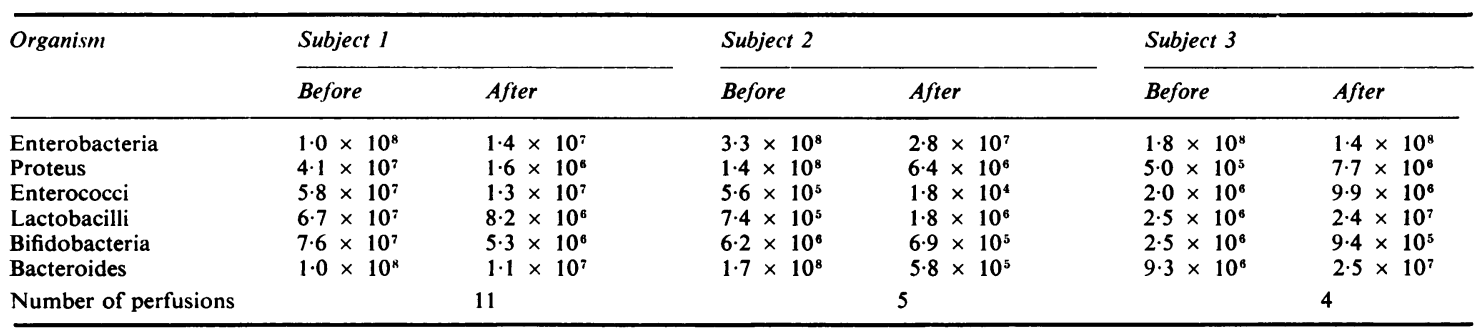

Table The average mean counts $\left(\log _{10}\right.$ organisms per $\left.m l\right)$ of the major groups of colonic organisms present in the perfusion effluent from three subjects before and after two hours perfusion at $10 \mathrm{ml}$ per minute.

response of the third subject was quite different. Four perfusions were performed. The mean counts of four groups of organisms, ie, Proteus mirabilis, enterococci, lactobacilli, and bacteroides, were actually higher after perfusion than before, whilst those of the two other groups, enterobacteria and bifidobacteria, were little changed.

On occasions when the same subject was perfused twice on the same day with about a two-hour gap between the end of the first perfusion and the start of the next, the response of the flora was variable. In one instance, counts at the start of the second perfusion had regained the level recorded before the start of the first perfusion. More usually, initial counts at the start of the second perfusion were similar to those recorded at the end of the first perfusion, and a further slight fall, or no change, was recorded by the end of the second perfusion. Reducing the $\mathrm{pH}$ of the perfusing effluent did not affect the degree of reduction in counts to any measurable extent, ie, perfusion with a solution of pH $4 \cdot 2$ did not reduce counts more than perfusion with solutions of a $\mathrm{pH}$ ranging from $7 \cdot 2$ to $8 \cdot 9$.

\section{Rapid perfusion at $50 \mathrm{ml}$ per minute}

Two subjects were perfused at $50 \mathrm{ml}$ per min for one hour, following immediately after perfusion at $10 \mathrm{ml}$ per min for two hours (fig 2). In the first subject, this additional perfusion had little effect on the counts of Esch. coli and lactobacilli; counts of bifidobacteria rose by 2 logs, and veillonella and anaerobic streptococci were recovered from the effluent for the first time during perfusion at counts of $8.0 \times 10^{3}$ and $6.0 \times 10^{4}$ per $\mathrm{ml}$ respectively. However, bacteroides, which were present after two hours' perfusion at $10 \mathrm{ml}$ per min, were not recovered from the effluent after the rapid perfusion. In the second subject, the effect of washing the colon through with over 4 litres of fluid was to reduce the total viable count from $1.2 \times 10^{6}$ per $\mathrm{ml}$ at the start of the rapid perfusion to $9.5 \times 10^{3}$ per $\mathrm{ml}$ at the end. This reduction included 2 to $3 \log$ falls in the counts of all major groups of organisms studied.

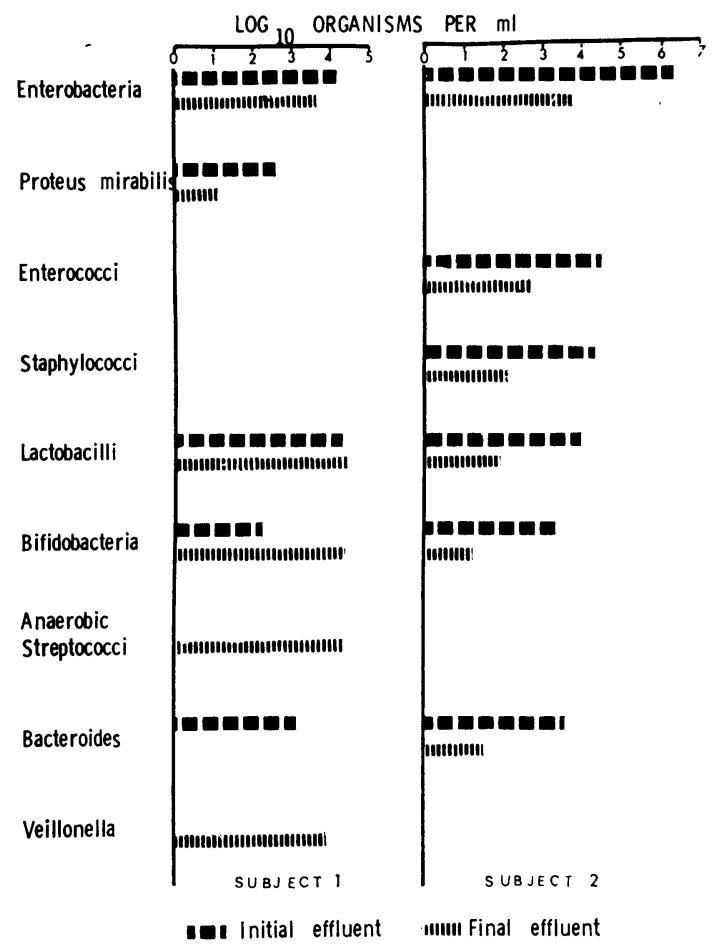

Fig. 2 Counts of organisms in the perfusion effluent at the start and finish of one hour's perfusion at $50 \mathrm{ml}$ per minute.

\section{Antibiotic perfusions}

Two two-hour $10 \mathrm{ml} / \mathrm{min}$ perfusions were performed on one patient. On the first occasion a fall of between 1 and 2 logs was recorded for bacteroides, enterococci, lactobacilli, and bifidobacteria. Counts of Esch. coli fell by about half a $\log$ and the counts of Proteus mirabilis remained unchanged. These changes were similar to those observed during $10 \mathrm{ml}$ per minute perfusions, to which no antibiotics had been added. With the exception of Proteus mirabilis 
counts of all the organisms were still greater than $10^{5}$ per $\mathrm{ml}$ at the end of the perfusion, counts of bacteroides and bifidobacteria being greater than $10^{6}$ per $\mathrm{ml}$. Organisms isolated during this perfusion were inhibited by the perfusing solution by $1 / 10$, but not $1 / 20$, dilutions of the issuing effluent. A similar perfusion was performed four months later, but this time none of the major groups of organisms could be recovered from the perfusion effluent at the end of the perfusion.

\section{Discussion}

The presence of large numbers of a variety of organisms in the excluded colonic segment is not so surprising as it might appear at first in view of the plentiful supply of endogenous material such as dead bacterial and epithelial cells and substances excreted into the colon that are available for bacterial utilization. It seems likely that most of the organisms present in the excluded colon originated from the intact colon, especially as similar serotypes of Esch. coli were obtained from both sites in two subjects.

The presence of so many organisms in the excluded colon is not without practical implications to the patient. Although divorced from the remainder of the gut, the excluded colon retains its blood supply, so that substances, eg, ammonia, elaborated by organisms within it may still be absorbed to the benefit or detriment of the host.

These studies demonstrate the dangers involved in assuming that the colon has been effectively cleansed of bacteria by perfusion. It is not possible to tell whether or not a solution is free of bacteria simply because it looks clear. Clear effluents resembling tap water may contain up to $10^{5}$ organisms/ $\mathrm{ml}$. Extreme measures, ie, prolonged rapid perfusion, or perfusion with solutions containing antibiotics were necessary to obtain any substantial reduction in counts, which in any case were of short duration, and completely unpredictable. The effect produced by two hours of perfusion at $10 \mathrm{ml}$ per minute was slight, and any reduction in counts was reversed within a few hours of cessation of perfusion, suggesting that such procedures should be used regularly if any therapeutic effect is to be maintained. The $\mathrm{pH}$ of the perfusing solution did not alter the degree of reduction in counts, so no additional benefit would be obtained by perfusing subjects with solutions of low pH than would be obtained with a neutral solution. The fact that in this instance dilutions of the effluent were made immediately it was obtained would tend to eliminate any adverse effects of prolonged exposure of organisms to low $\mathrm{pH}$ anyway.

Different subjects responded to perfusion in different ways. Perfusion tended to raise rather than lower the counts of most of the major groups of organisms present in the issuing effluent from one subject. A similar and perhaps related phenomenon was the appearance in the high flow rate effluents of organisms not recovered during slower perfusions. Such rises in counts during perfusion and the appearance of new organisms probably resulted from the dislodging of organisms more closely associated with the colonic mucosa or situated in mucosal folds, which were left undisturbed by perfusion at $10 \mathrm{ml}$ per min, but which were washed off or out by perfusion at $50 \mathrm{ml}$ per minute. Obviously a similar situation in which organisms present in luminal contents might differ either qualitatively or quantitatively from those more intimately associated with the intestinal mucosa may well exist in the intact intestine (O'Grady and Vince, 1971).

Why perfusion of the same subject with antibiotic-containing solutions gave such conflicting results on the two occasions on which it was performed is not clear. In both instances organisms recovered before and after perfusion were sensitive to the agents used, and were inhibited by a 1/10 solution of the perfusing agent. It is possible that the presence of antibiotics in the effluent that was used to inoculate the plates masked the presence of organisms at counts of $10^{2}$ or less, but higher counts should have been detected. It is clear from these studies that perfusion with a solution containing appropriate concentrations of agents to which the organisms are sensitive will not necessarily deplete the bacterial population in a predictable manner.

In many instances the presence of bacteria in perfusing effluents is of little or no importance, but in studies involving urea hydrolysis and ammonia production, the presence of urea-splitting and ammonia-producing organisms in the perfusion effluent could give misleading results, especially if trouble is not taken to halt all ammonia production immediately the specimen is obtained. Their continuing presence even after prolonged perfusion indicates that recovery of urea during perfusion (Wolpert, Phillips, and Summerskill, 1971) is not due to complete cleansing of the colon of its bacterial population. It is probably due to the fact that organisms are exposed to the urea for too short a period under not particularly favourable conditions, so that any reduction in urea content is too small to be detected.

\footnotetext{
References

Bown, R., Sladen, G. E., Clark, M. L., and Dawson, A. M. (1971). The production and transport of ammonia in the human colon. Gut, 12, 863.

Bown, R., Sladen, G. E., Rousseau, B., Gibson, J. A., Clark, M. L., and Dawson, A. M. (1972). A study of water and electrolyte transport by the excluded human colon. Clin. Sci., 43, 891-902.
} 
Castell, D. O., and Moore, E. W. (1968). Ammonia absorption from human colon: the role of non-ionic diffusion. Clin. Res., 16, 528.

Hamilton, J. D., Dyer, N. H., Dawson, A. M., O’Grady, F. W. Vince, A., Fenton, J. C. B., and Mollin, D. L. (1970). Assessment and significance of bacterial overgrowth in the small bowel. Quart. J. Med., 39, 265-285.

Lancet (1971). Leading Article. Urea metabolism in man. Lancet, 2 , 1407-1408.

O'Grady, F. W., and Vince, A. (1971). Clinical and nutritional significance of intestinal bacterial overgrowth. J. clin. Path., 24, Suppl. (Roy. Coll. Path.), 5, 130-137.
Wolpert, W., Phillips, S. F., and Summerskill, W. H. J. (1970) Ammonia production in the human colon: effects of cleansing, neomycin and acetohydroxamic acid. New Engl. J. Med., 283, 159-164.

Wolpert, E., Phillips, S. F., and Summerskill, W. H. J. (1971). Transport of urea and ammonia production in the human colon. Lancet, 2, 1387-1390.

Zeegen, R., Drinkwater, J. E., Fenton, J. C. B., Vince, A., and Dawson, A. M. (1970). Some observations on the effects of treatment with lactulose on patients with chronic hepatic encephalopathy. Quart. J. Med., 39, 245-263. 